\title{
Quality and Yield Characteristics of Potato (Solanum tuberosum L.) Grown at Paddy Field in Spring Season
}

\author{
Ju Sung Im ${ }^{1 *}$, Ji Hong Cho ${ }^{1}$, Dong Chil Chang ${ }^{1}$, Yong Ik Jin ${ }^{1}$, Young Eun Park ${ }^{1}$, Chung Gi Chun ${ }^{1}$, \\ Dong Un Kim ${ }^{1}$, Hong Seob Yü, Jong Nam Lee ${ }^{1}$, and Myung Jun Kim ${ }^{2}$ \\ ${ }^{1}$ Highland Agriculture Research Center, National Institute of Crop Science, Rural Development Administration, \\ Pyeongchang 232-955, Korea \\ ${ }^{2}$ Pepper Institute of Imsil-gun Agricultural Technology Center, Imsil 566-822, Korea
}

\begin{abstract}
This study was conducted to determine the characteristics of quality and yield in potatoes grown at paddy field before rice transplantation during the spring season. Three potato cultivars ('Jowon', 'Haryeong', and 'Goun') were grown in Gangneung (asl $5 \mathrm{~m}$ ) and Seocheon (asl $20 \mathrm{~m}$ ). In both locations, weather condition belonged to the fourth zone (spring cropping) in potato production location's distribution of Korea. Daily mean soil temperature in both the locations was $0.2-0.6^{\circ} \mathrm{C}$ lower than air temperature, while soil moisture was adequate level to potato growth in spite of spring drought. TR ratio was not affected by location, but by cultivar. Specific gravity, starch content, dry matter rate, and yield were significantly influenced by location and by cultivar. There was no difference in total tuber number by location, however there was a large gap in marketable tuber yield according to locations and cultivars. There were high negative relationships between yield and main qualities such as dry matter rate and starch content, while high positive correlation was observed between main qualities. It was possible to produce potato before rice transplanting at drained paddy fields located in representative two locations of potato spring cropping and their characteristics in growth and quality were similar to those generally well known in upland cultivation. Paddy field was thought to be more favorable than upland in terms of available soil moisture supply against spring drought. Further research, however, was needed to increase soil temperature and also preliminary review on proper cultivar according to location seemed to be needed for high yield.
\end{abstract}

Additional key words: dry matter content, Solamum tuberosum L., specific gravity, starch content

\section{Introduction}

Potato (Solamum tuberosum L.) is a very important tuberous crop belonging to the perennial Solanaceae family (Hanneman, 1989). It is the world's fourth-largest food crop, following maize, rice, and wheat (FAO, 2008) and is cultivated in more than 100 countries (Kawchuck et al., 1996). It is well known that potato was introduced into Korea around the 18th century and was eaten as an emergency crop against serious famine (Cho et al., 2003).

Meanwhile, potato is being considered as the perfect food for its high contents in vitamins, minerals, and phytochemicals such as phenolic compounds and carotenoids (Brown, 2005; Burton, 1989; Kolasa, 1993; Love and Pavek, 2008). Therefore, its consumption has been increasing as food in a market and as raw material of chip or starch in processing industry. In recent, potato has also attracted the attention as an ecofriendly raw material for bio-ethanol production against global warming and high oil prices (Jang et al., 2011).

It has been produced annually about $604,000 \mathrm{t}$ at 22,000 ha in Korea (MIFAFF, 2011). However, it is insufficient to meet the domestic demand on potato for food and processing raw materials of chip or starch, so about $98,567 \mathrm{t}$ as dried potato and starch type has been imported annually (KATI, 2011). In addition, the import price has been steadily increasing according to the worldwide rise in grain prices (KATI, 2011). Thus, domestic self-supply system of potato has been needed for the stable development of potato processing industry as

\footnotetext{
*Corresponding author: imjusung@korea.kr

※ Received 21 March 2012; Revised 9 October 2012; Accepted 9 November 2012. This study was supported from the project of 2011 'Development of Potato Bio-energy Production Technique by Cropping System Improvement' of HARC (NICS), Rural Development Administration
} 
well as aspects of food security (RDA, 2005).

Then, to establish sustainable self-supply system of potato in Korea, two problems should be solved. The first is a lack of farmland and the second is injury by successive cropping. That is, cropping systems are basically required that raise farmland use efficiency and that reduce diseases and physiological disorders caused by successive cropping.

There are four cropping systems (spring, summer, fall, and overwintering) according to growing seasons of potato (RDA, 2005). And at these cropping systems, upland is mainly used for potato production and drained paddy field is used partly at any southern location in spring season. There is a huge potential of potato production at southern and eastern locations in spring cropping. Price of potato is very good in May and early June. And before rice transplanting, paddy field is empty during spring season.

Therefore, if potato can be grown well at paddy field before rice transplanting in spring season, it could be a profitable cropping system solving the aforementioned problems in Korea. However, there are no studies on potato production before rice transplanting at paddy field and also none on qualities or yield characteristics of the one.

This study was conducted to determine qualities and yield characteristics of potato grown at drained paddy field located in representative two locations of potato spring cropping and also to investigate the possibility of introducing of potato as the crop before rice transplanting.

\section{Materials and Methods}

Three potato cultivars ('Jowon', 'Haryeong', and 'Goun'.) were grown at drained paddy fields located in Gangneung, Gangwon (asl $5 \mathrm{~m}$ ) and Seocheon, Chungnam (asl $20 \mathrm{~m}$ ).

Soil characteristic of this experiment's fields was shown at Table 1. At one month before sowing, field was plowed after whole layer placement of farmyard manure $(2,000 \mathrm{~kg} \cdot 10$ $\left.\mathrm{a}^{-1}\right)$ and lime $\left(200 \mathrm{~kg} \cdot 10 \mathrm{a}^{-1}\right)$. And then, $150 \mathrm{~kg} \cdot 10 \mathrm{a}^{-1}$ of compound fertilizer $(\mathrm{N}: \mathrm{P}: \mathrm{K}=10: 10: 11$, Potato 1 Ho, Nam-hae Chem., Yeosu, Korea) was applied at a week before sowing and rows were made and then mulched with black P.E. film at three days before sowing. Sowing space was $25 \times 80 \mathrm{~cm}$. Sowing date was March 5 and harvest date was June 5 in 2011. Field management was carried out according to the standard cultivation techniques of potato (RDA, 2005). A randomized complete block design with three replications was used for this experiment. At harvest, forty plants in each plot were sampled and then growth factors (top part weight, root part weight, and TR ratio), main qualities (specific gravity, dry matter rate, starch content, etc.), and yield factors (marketable tuber numbers, mean tuber weight, marketable tuber rate, etc.) were investigated.

Specific gravity was determined by using the equation of [specific gravity = (a weight in air) / (a weight in air - a weight in water)] within one day of harvest (Kleinkopf et al., 1987).

For dry matter rate, potato was cleaned and cut into small pieces after weighing. Then the pieces were put into a deepfreezer as soon as possible. They were frozen at $-80^{\circ} \mathrm{C}$ for $24 \mathrm{~h}$ and then lyophilized at $-70^{\circ} \mathrm{C}$ under the vacuum statement using freeze dryer system (PVTFD 20R, Il Shin Lab Co. Ltd., Yangju, Korea). Dry matter rate was expressed by the percentage of the weight after drying to the weight before drying.

Dried samples were ground to powder and then stored at $-20^{\circ} \mathrm{C}$ until used for starch analysis. Starch content was determined by using the method of Miller (1959) with 3,5-dinitrosalicylic acid. At first, $1 \mathrm{~g}$ of potato powder was put into the flask $(250 \mathrm{~mL})$ and distilled water $(60 \mathrm{~mL})$ and $5 \%(\mathrm{v} / \mathrm{v}) \mathrm{HCl}(100 \mathrm{~mL})$ were added into the flask. The flask was heated for two hours and the solution in the flask was neutralized by using $28 \%(\mathrm{w} / \mathrm{v}) \mathrm{NaOH}$ after cooling. The solution was diluted and reducing sugar was analyzed by using 3,5-dinitrosalicylic acid and then starch content was calculated.

Marketable tuber rate was calculated as the percentage of marketable tuber yield over $80 \mathrm{~g}$ to total yield. Other yield characteristics were measured according to the analysis standard of agricultural test and research (RDA, 2003). Data were analyzed by analysis of variance (ANOVA) using the statistical package of SAS enterprise guide 4.3 (SAS Institute Inc., Cary, NC, USA) and mean separation was determined by Duncan's multiple range test (DMRT) at 5\% level.

\section{Results and Discussion}

Spring cropping of potato has two unfavorable environmental

Table 1. The initial chemical properties of surface soil $(10 \mathrm{~cm}$ ) of the experimental fields located in Gangneung (asl $5 \mathrm{~m})$ and Seocheon (asl $20 \mathrm{~m}$ ).

\begin{tabular}{|c|c|c|c|c|c|c|c|c|c|}
\hline \multirow{2}{*}{ Location } & \multirow{2}{*}{$\begin{array}{c}\mathrm{pH} \\
(1: 5)\end{array}$} & \multirow{2}{*}{$\begin{array}{c}E C \\
\left(\mathrm{dS} \cdot \mathrm{m}^{-1}\right)\end{array}$} & \multirow{2}{*}{$\begin{array}{c}\mathrm{P}_{2} \mathrm{O}_{5} \\
\left(\mathrm{mg} \cdot \mathrm{kg}^{-1}\right)\end{array}$} & \multirow{2}{*}{$\begin{array}{c}\text { O.M. } \\
(\%)\end{array}$} & \multicolumn{4}{|c|}{ Ex. Cat $\left(\mathrm{cmol}(+) \cdot \mathrm{kg}^{-1}\right)$} & \multirow{2}{*}{ 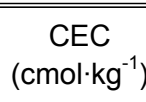 } \\
\hline & & & & & $\mathrm{Ca}$ & $\mathrm{Mg}$ & $\mathrm{K}$ & $\mathrm{Na}$ & \\
\hline Gangneung & 6.5 & 0.32 & 222.9 & 2.34 & 4.15 & 2.54 & 0.15 & 0.30 & 10.12 \\
\hline Seocheon & 5.4 & 0.18 & 102.4 & 3.10 & 3.32 & 0.92 & 0.50 & 0.34 & 10.62 \\
\hline
\end{tabular}


problems to the cultivation. The first, leaf emergence is delayed due to low temperature at the sowing season. The second, spring drought is very severe between leaf emergence and tuber initiation/enlargement known as sensitive growth phases to drought stress (MacKerron and Jefferies, 1986; Robins and Domingo, 1956; Shimsi and Susnoschi, 1985; van Loon, 1981). Therefore, it is very important to secure adequate temperature and soil moisture for potato spring cropping (RDA, 2005). Potato production locations have been divided into six zones according to the weather conditions.

In both locations of this study, weather condition was shown at Fig. 1. Accumulative temperature $\left(1,675.9^{\circ} \mathrm{C}\right.$ in Gangneung and $1,604.0^{\circ} \mathrm{C}$ in Seocheon(Fig. 1A)), water

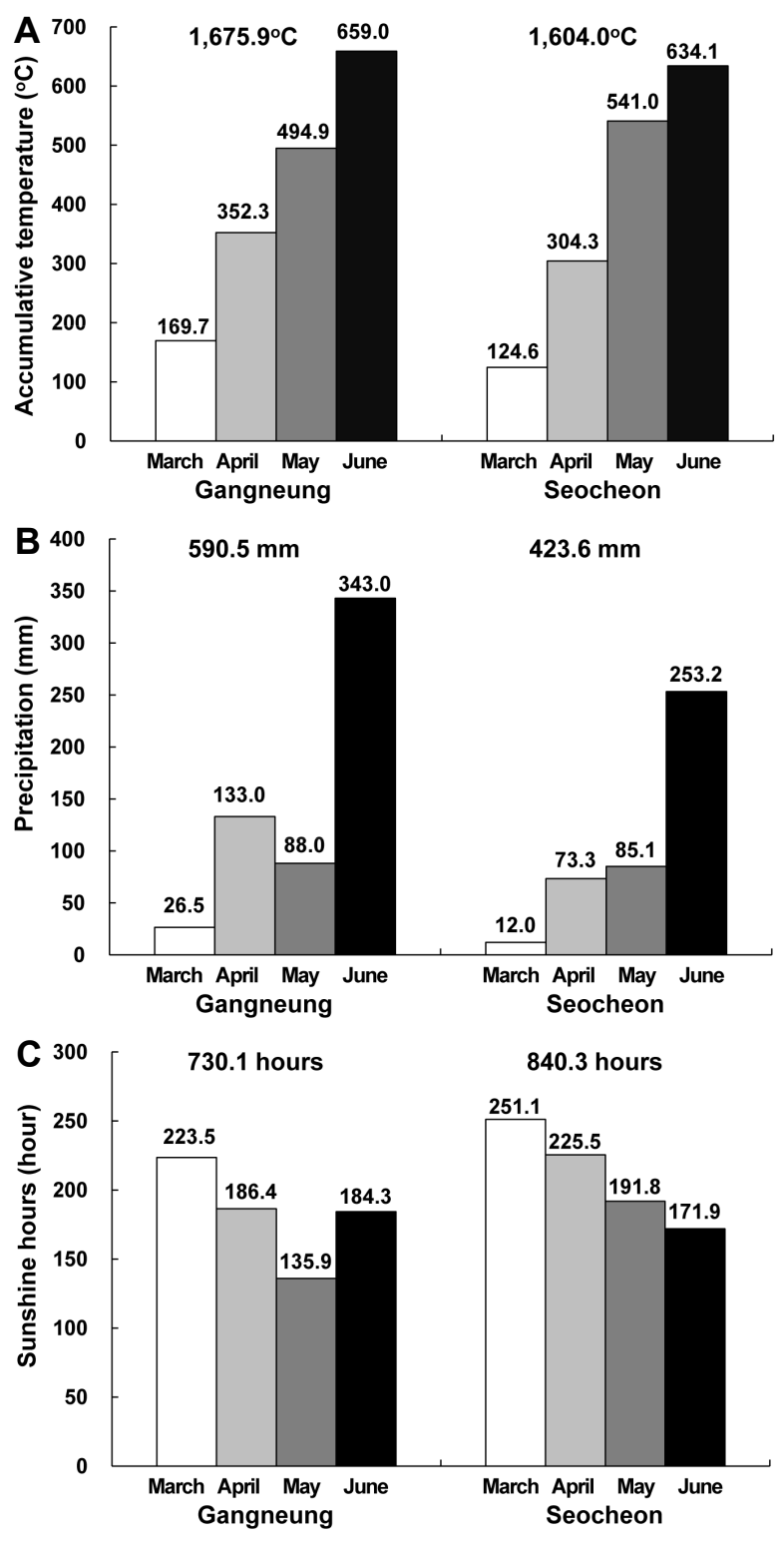

Fig. 1. Accumulative temperature $\left({ }^{\circ} \mathrm{C}\right)(\mathrm{A})$, precipitation $(\mathrm{mm})$ (B), and sunshine hours (C) during potato cultivation period in Gangneung (asl $5 \mathrm{~m}$ ) and Seocheon (asl $20 \mathrm{~m}$ ). supply through precipitation $(590.5 \mathrm{~mm}$ and $423.6 \mathrm{~mm}$, respectively (Fig. 1B)), and sunshine hours (730.1 h and $840.3 \mathrm{~h}$, respectively (Fig. 1C)) were typical ones of the fourth zone (spring cropping) in potato production location's distribution of Korea (RDA, 2005). Daily mean soil temperature in March (early growth time) was $5.3^{\circ} \mathrm{C}$ in Gangneung and $3.4^{\circ} \mathrm{C}$ in Seocheon (Fig. 2A). Daily mean soil moisture content from March to May (spring drought season) was ranging from 33.2 to $49.8 \%$ in Gangneung and from 28.8 to $46.7 \%$ in Seocheon (Fig. 2B).

In this study, soil moisture condition, in spite of the spring drought, was in adequate level to potato growth. It is well known that paddy field with high loam soil has better water retention capacity (Stakman, 1974). In terms of overcoming of spring drought, paddy field might be better than upland. Meanwhile, black plastic mulch used in this study, even though less than transparent plastic mulch, has been generally known to increase the soil temperature (Clarkson, 1960; Courter, 1964). Then, in this study, daily mean soil temperature was $0.2-0.6^{\circ} \mathrm{C}$ lower than daily mean air temperature. It might be because of the soil characteristic of paddy field containing more moisture. Soil temperature can be changed as affected by mulch materials (Collins, 1976; Cui, 1999; Ekern, 1967). Therefore, further research will be needed on effective method for an increase of soil temperature in spring cropping using paddy field.

Top part weight (TW) and root part weight (RW) were

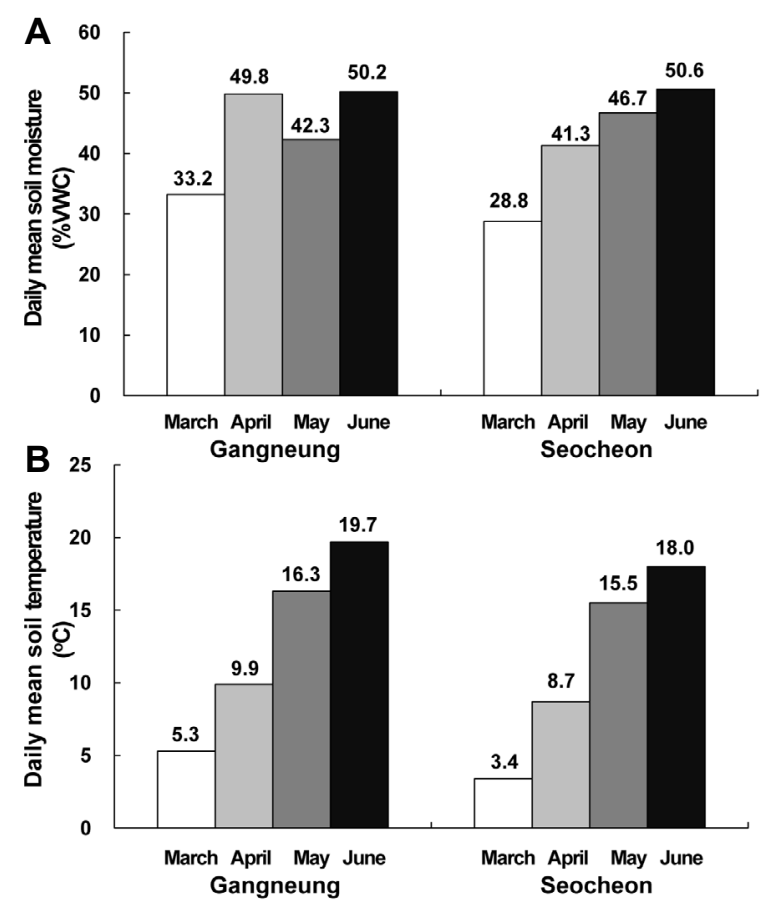

Fig. 2. Daily mean soil temperature $\left({ }^{\circ} \mathrm{C}\right)(\mathrm{A})$ and daily mean soil moisture (\% VWC) (B) during potato cultivation period in Gangneung (asl $5 \mathrm{~m}$ ) and Seocheon (asl $20 \mathrm{~m}$ ). 
significantly influenced by location, cultivar, and the interactions between location and cultivar (Table 2). TR ratio was not affected by location, but by cultivar and by the interactions between location and cultivar. This was similar to the result of early research on potato that there were differences among potato clones in growth of shoots and roots (Swiezynski et al., 1978) and, at paddy field, potato seemed to grow basically according to inherent characteristics of cultivars.

Meanwhile, specific gravity (SG) has been extensively used as an easy measure of dry matter rate (DMR) and starch content (SC) being considered as very important qualities in potato processing (Brandt, 1979; Lisinska and Leszczynski, 1989; Pavlista, 1997). Higher DMR in potato mean higher product yield and also less energy input such as an oil in processing. It has been reported that SC accounted for as much as $60-80 \%$ of the tuber's DMR and starch was the major storage component of tubers (Kolbe and Stefan-Beckmann,
1997).

In this study, SG, SC, and DMR were most significantly influenced by location and by cultivar (Table 3) and DMR was also influenced by the interactions between location and cultivar. By a number of researchers, DMR was reported to be differed as affected by growth phase and environmental factors such as available soil moisture or temperature as well as genotype (Burton, 1966; Ifenkwe et al., 1974; Kim, 1991; Shimshi and Susnoschi, 1985).

Especially, water supply such as rainfall in early growth increase DMR through increasing $\mathrm{SC}$, while the one in maturity of tuber increase the moisture content of tubers and it eventually lead to a reduction in dry matter (Iritani, 1981; Jefferies and MacKerron, 1987). In this study, DMR in Seocheon (it was ranging from 19.3 to $25.1 \%$ between cultivars) was much higher than that in Gangneung (it was ranging from 14.3 to $19.5 \%$ between cultivars). It might be caused

Table 2. Top and root part weights, and TR ratios in three potato cultivars ('Jowon', 'Haryeong', and 'Goun') grown at drained paddy fields located in Gangneung (asl $5 \mathrm{~m}$ ) and Seocheon (asl $20 \mathrm{~m}$ ) according to the spring cropping.

\begin{tabular}{|c|c|c|c|c|}
\hline Location & Cultivar & $\begin{array}{l}\text { Top part weight } \\
\text { (g/10 plants) }\end{array}$ & $\begin{array}{l}\text { Root part weight } \\
\text { (g/10 plants) }\end{array}$ & $\begin{array}{c}\text { TR ratio } \\
\text { (Top/Root) }\end{array}$ \\
\hline & Jowon & $1,769.0 \pm 292.8^{z} b^{y}$ & $10,330.3 \pm 787.8 a$ & $0.170 \pm 0.016 b$ \\
\hline \multirow[t]{3}{*}{ Gangneung } & Haryeong & $4,381.3 \pm 549.2 a$ & $7,744.0 \pm 1,065.8 b$ & $0.568 \pm 0.046 a$ \\
\hline & Goun & $5,167.7 \pm 760.5 a$ & $8,281.7 \pm 696.0 b$ & $0.623 \pm 0.058 a$ \\
\hline & Jowon & $1,439.3 \pm 231.6 b$ & $4,912.7 \pm 302.7 a$ & $0.292 \pm 0.035 b$ \\
\hline \multirow[t]{2}{*}{ Seocheon } & Haryeong & $2,226.3 \pm 398.9 a$ & $4,622.3 \pm 344.6 a$ & $0.485 \pm 0.107 a$ \\
\hline & Goun & $2,422.7 \pm 266.0 a$ & $4,656.7 \pm 381.1 a$ & $0.524 \pm 0.085 a$ \\
\hline \multicolumn{2}{|l|}{ Location } & $* * *$ & $* * *$ & ns \\
\hline \multicolumn{2}{|l|}{ Cultivar } & $* * *$ & ** & $* * *$ \\
\hline \multicolumn{2}{|c|}{ Location $\times$ Cultivar } & ** & * & * \\
\hline
\end{tabular}

${ }^{z}$ Each value represents the mean and standard deviation of three replicates.

${ }^{\mathrm{y}}$ Means followed by the same letters within columns are not significantly different by DMRT at $P \leq 0.05$.

ns,,,$* * * * *$ Non-significant or significant at $P \leq 0.05,0.01$, or 0.001 , respectively.

Table 3. Qualities, physiological disorder, and damage by disease in three potato cultivars ('Jowon', 'Haryeong', and 'Goun') grown at drained paddy fields located in Gangneung (asl $5 \mathrm{~m}$ ) and Seocheon (asl $20 \mathrm{~m}$ ) according to the spring cropping.

\begin{tabular}{|c|c|c|c|c|c|c|}
\hline Location & Cultivar & Specific gravity & $\begin{array}{c}\text { Starch } \\
\text { content } \\
(\%)\end{array}$ & $\begin{array}{l}\text { Dry matter rate } \\
\qquad(\%)\end{array}$ & $\begin{array}{c}\text { Physiological } \\
\text { disorder } \\
(\%)\end{array}$ & $\begin{array}{c}\text { Damage by } \\
\text { disease } \\
(\%)\end{array}$ \\
\hline & Jowon & $1.057 \pm 0.003^{z} c^{y}$ & $10.9 \pm 0.6 c$ & $14.3 \pm 0.2 b$ & 0.4 & 0.5 \\
\hline \multirow[t]{3}{*}{ Gangneung } & Haryeong & $1.073 \pm 0.001 b$ & $13.6 \pm 0.1 b$ & $18.8 \pm 1.3 a$ & 0.7 & 0.4 \\
\hline & Goun & $1.077 \pm 0.001 \mathrm{a}$ & $14.4 \pm 0.2 a$ & $19.5 \pm 0.1 a$ & 0.3 & 0.2 \\
\hline & Jowon & $1.085 \pm 0.002 b$ & $15.9 \pm 0.4 b$ & $19.3 \pm 0.8 c$ & 0.5 & 0.2 \\
\hline \multirow[t]{2}{*}{ Seocheon } & Haryeong & $1.102 \pm 0.005 a$ & $18.3 \pm 0.3 a$ & $26.5 \pm 0.6 a$ & 0.3 & 0.2 \\
\hline & Goun & $1.108 \pm 0.001 a$ & $18.5 \pm 0.1 a$ & $25.1 \pm 0.3 b$ & 0.3 & 0.3 \\
\hline Location & & $* * *$ & $* * *$ & $* * *$ & ns & * \\
\hline Cultivar & & $* * *$ & $* * *$ & $* * *$ & ns & ns \\
\hline Location $\times \mathrm{C}$ & & ns & ns & * & ns & ns \\
\hline
\end{tabular}

${ }^{z}$ Each value represents the mean and standard deviation of three replicates.

${ }^{\mathrm{y}}$ Means followed by the same letters within columns are not significantly different by DMRT at $P \leq 0.05$.

ns, ${ }^{* * * *}$ Non-significant or significant at $P \leq 0.05$, or 0.001 , respectively. 
by much more precipitation in Gangneung during June (the phase of tuber maturity). Meanwhile, in potato chip processing, adequate DMR and SG were known as over $21 \%$ and over 1.082, respectively (Park, 2003). Judging from levels of DMR and SG in Seocheon, it seemed that, through review on proper location, paddy field could be used for the production of raw materials required in potato processing industry.

Physiological disorder such as a tuber cracking was not influenced by location or cultivar. Damage by diseases such as a potato blight was influenced only by location. These both factors had been considered as the main causes of yield reduction. Then, in two locations, the percentage of both factors was very low (under 1\%). It had been reported by a number of workers that crop rotation and flooding treatment were helpful to control insects and soil diseases caused by fungi and bacteria (Genung, 1970; Katan, 2000; Stover, 1979). Like in these reports, rotation with rice seemed to be helpful to reduce the injury by potato successive cropping.
Total tuber number, as shown at Table 4, was greatly dependent on cultivar, but not on location. Marketable tuber number (MTN) was most significantly differed by cultivar as well as by location. MTN in Gangneung was more than that in Seocheon and, between cultivars, the one of 'Jowon' was the most in both locations. Mean tuber weight (MTW) and marketable tuber rate (MTR) were most significantly influenced by location, cultivar, and the interactions between location and cultivar. Yield was also greatly dependent on location and on cultivar, but not on the interactions between both factors. As shown at Fig. 3A, yield in Gangneung (it was ranging from 3,202 to $4,778 \mathrm{~kg} \cdot 10 \mathrm{a}^{-1}$ between cultivars) was much more than that in Seocheon (it was ranging from 1,017 to $1,959 \mathrm{~kg} \cdot 10 \mathrm{a}^{-1}$ between cultivars). And, between cultivars, the one of 'Jowon' was the highest in both locations.

In official statistics (MIFAFF, 2011), average yield of potato spring cropping during the recent five years, was ranging from 2,415 to $2,930 \mathrm{~kg} \cdot 10 \mathrm{a}^{-1}$. As compared with these, the yield in Gangneung was very high, while in

Table 4. Yield characteristics of three potato cultivars ('Jowon', 'Haryeong', and 'Goun') grown at drained paddy fields located in Gangneung (asl $5 \mathrm{~m}$ ) and Seocheon (asl $20 \mathrm{~m}$ ) according to the spring cropping.

\begin{tabular}{|c|c|c|c|c|c|c|}
\hline \multirow[t]{2}{*}{ Location } & \multirow[t]{2}{*}{ Cultivar } & \multicolumn{2}{|c|}{$\begin{array}{l}\text { Number of tubers } \\
\text { (/10 plants })\end{array}$} & \multirow{2}{*}{$\begin{array}{l}\text { Mean tuber weight } \\
\text { (g/tuber) }\end{array}$} & \multirow{2}{*}{$\begin{array}{c}\text { Marketable tuber } \\
\text { rate } \\
(\%)\end{array}$} & \multirow{2}{*}{$\begin{array}{c}\text { Yield } \\
\text { (g/10 plants) }\end{array}$} \\
\hline & & Total & Marketable & & & \\
\hline \multirow{3}{*}{ Gangneung } & Jowon & $73.7 \pm 3.5^{z} b^{y}$ & $51.3 \pm 1.5 a$ & $186.1 \pm 11.7 a$ & $92.6 \pm 1.2 a$ & $9,556.3 \pm 709.6 a$ \\
\hline & Haryeong & $66.3 \pm 6.1 b$ & $39.0 \pm 3.5 b$ & $168.3 \pm 8.4 a$ & $84.9 \pm 1.1 b$ & $6,577.3 \pm 845.1 b$ \\
\hline & Goun & $89.0 \pm 8.2 a$ & $46.3 \pm 3.8 a$ & $138.5 \pm 10.2 b$ & $76.8 \pm 1.5 c$ & $6,404.3 \pm 530.8 b$ \\
\hline \multirow{3}{*}{ Seocheon } & Jowon & $55.0 \pm 7.2 b$ & $30.7 \pm 2.5 a$ & $127.9 \pm 3.3 a$ & $79.4 \pm 3.2 a$ & $3,917.0 \pm 235.2 a$ \\
\hline & Haryeong & $86.7 \pm 4.2 a$ & $19.6 \pm 3.2 b$ & $103.2 \pm 3.7 c$ & $43.6 \pm 6.0 b$ & $2,034.0 \pm 374.8 b$ \\
\hline & Goun & $78.0 \pm 4.0 a$ & $20.0 \pm 3.5 b$ & $112.1 \pm 5.0 b$ & $48.3 \pm 7.2 b$ & $2,252.3 \pm 470.5 b$ \\
\hline Location & & ns & $* * *$ & $* * *$ & $* * *$ & $* * *$ \\
\hline Cultivar & & $* * *$ & $* \star *$ & $* * *$ & $* * *$ & $* * *$ \\
\hline Location $\times \mathrm{C}$ & & $* * *$ & ns & ** & $* * *$ & ns \\
\hline
\end{tabular}

${ }^{\mathrm{z}}$ Each value represents the mean and standard deviation of three replicates.

${ }^{\mathrm{y}}$ Means followed by the same letters within columns are not significantly different by DMRT at $P \leq 0.05$.

$\mathrm{ns}^{* * *, * * *}$ Non-significant or significant at $P \leq 0.01$, or 0.001 , respectively.
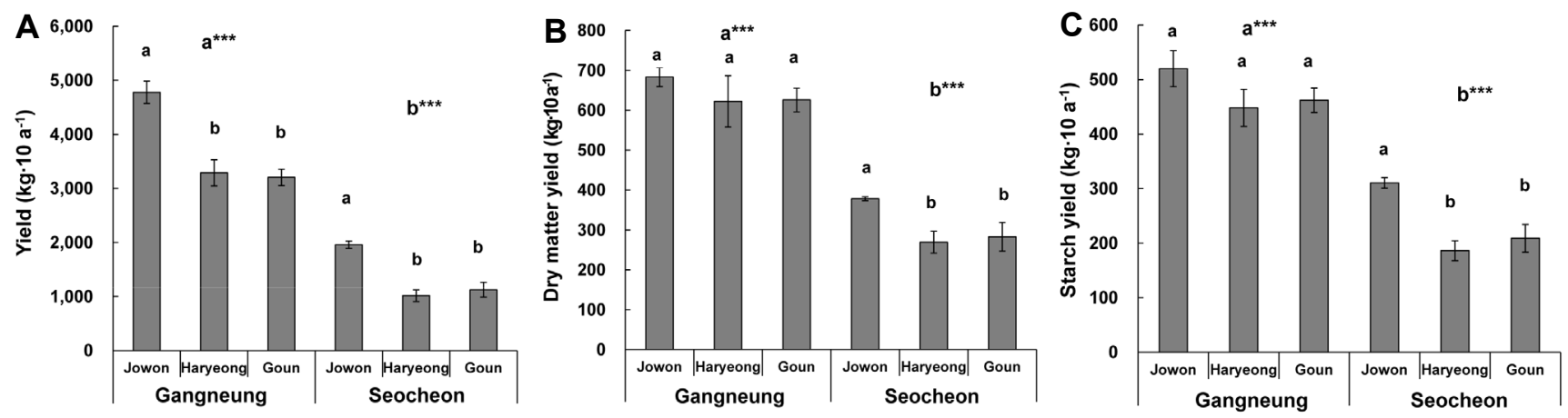

Fig. 3. Yield (A), dry matter yield (B), and starch yield (C) in three potato cultivars ('Jowon', 'Haryeong', and 'Goun') grown at drained paddy fields located in Gangneung (asl $5 \mathrm{~m}$ ) and Seocheon (asl $20 \mathrm{~m}$ ) according to the spring cropping. The same letters within columns are not significantly different by DMRT at $P \leq 0.05$ and ${ }^{* * *}$ Significant at $P \leq 0.001$. 
Seocheon very low. Despite that there was no difference in total tuber number by location (Table 4), the low yield in Seocheon, as shown at Fig. 4, was because the percentage of light tubers under $80 \mathrm{~g}$ was very high. That was, it was assumed that the tuber's enlargement after tuber formation was poor in Seocheon and this eventually led to low yield.

In general, it is well known that, in potato spring cropping, the yield depend on the degree of growth restriction by both low temperature at sowing time and spring drought during the phase of tuber enlargement (RDA, 2005). Also, it is very important to prolong the period of tuber enlargement as long as possible through quick sprout emergence (Lee, 2002) and to supply adequate water during tuber enlargement because mature potatoes contain about 74-82\% water (Burton, 1989). In this study, it seemed that higher soil temperature and soil moisture in Gangneung than those in Seocheon gave more

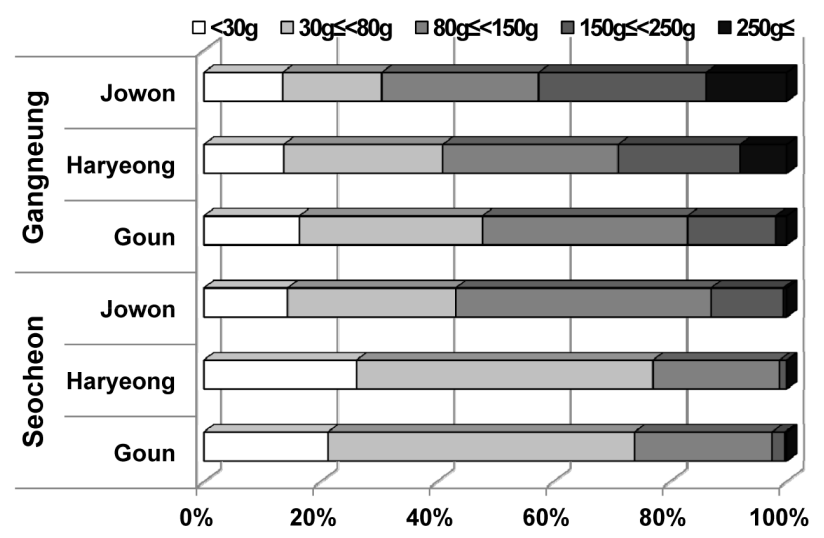

Fig. 4. Weight distribution of tubers harvested from three potato cultivars ('Jowon', 'Haryeong', and 'Goun') grown at drained paddy fields located in Gangneung (asl $5 \mathrm{~m}$ ) and Seocheon (asl $20 \mathrm{~m}$ ) according to the spring cropping. favorable synergistic effect on the promotion of early tuber growth and enlargement and eventually on fast maturity of tuber.

Meanwhile, dry matter yield (Fig. 3B) or starch yield (Fig. 3C), important qualities in potato processing, were higher in Gangneung than in Seocheon and it was basically caused by the difference in marketable tuber yield. Between cultivars, there were no difference in Gangneung, however, in Seocheon, 'Jowon' showed the most yield in both dry matter and starch in spite of the lowest DMR. It was also basically resulted from the difference in marketable tuber yield between cultivars. Thus, in case of paddy field cultivation for processing raw material, it was considered that, in addition to a selection of cultivar showing genetically high DMR or SC, a review of marketable tuber yield at paddy field should be needed.

The relationships between yield factors and main qualities were shown at Table 5. Kim (1991), in his study of spring cropping using cv. Atlantic in Gangneung, reported that yield was steadily increased from 80 to 100 days after sowing, however SG or dry matter content was decreased till the last harvest after showing the highest level at 90 days after sowing. Lee (2002) and Smith (1959) also reported similar results to that of Kim (1991). In their results, there were negative relationships between yield and DMR or SG at the harvest time for the highest yield. Meanwhile, it was well known by many studies that there were high positive correlations between dry matter, starch, and SG (Ekin, 2011; Ezekiel et al., 2003; Schippers, 1976; Vakis, 1978; van Es and Hartmans, 1987; Verma et al., 1971).

In this study, there were relatively high negative relationships between yield factors (marketable yield and mean tuber

Table 5. Correlation between marketable yield (MY), mean tuber weight (MTW), TR ratio, specific gravity (SG), dry matter rate (DMR), and starch content (SC) from three potato cultivars ('Jowon', 'Haryeong', and 'Goun') grown at drained paddy fields located in Gangneung (asl $5 \mathrm{~m}$ ) and Seocheon (asl $20 \mathrm{~m}$ ) according to the spring cropping.

\begin{tabular}{|c|c|c|c|c|c|c|c|}
\hline Location & Variable & MY & MTW & $\mathrm{TR}$ ratio & SG & DMR & SC \\
\hline \multirow{6}{*}{ Gangneung } & MY & 1 & $0.802^{* \star}$ & $-0.909^{* * *}$ & $-0.880^{* *}$ & $-0.859^{* *}$ & $-0.877^{* *}$ \\
\hline & MTW & & 1 & $-0.746^{*}$ & $-0.788^{*}$ & $-0.719^{\star}$ & $-0.792^{*}$ \\
\hline & TR ratio & & & 1 & $0.965^{* * *}$ & $0.926^{* * *}$ & $0.963^{* * *}$ \\
\hline & SG & & & & 1 & $0.937^{* * *}$ & $0.971^{* * *}$ \\
\hline & DMR & & & & & 1 & $0.934^{* * *}$ \\
\hline & SC & & & & & & 1 \\
\hline \multirow{6}{*}{ Seocheon } & MY & 1 & $0.922^{* * *}$ & $-0.865^{\star *}$ & $-0.892^{* *}$ & $-0.937^{* * *}$ & $-0.934^{* * *}$ \\
\hline & MTW & & 1 & $-0.754^{*}$ & $-0.779^{\star}$ & $-0.897^{* * *}$ & $-0.851^{* *}$ \\
\hline & TR ratio & & & 1 & $0.803^{* *}$ & $0.936^{\star * *}$ & $0.886^{* *}$ \\
\hline & SG & & & & 1 & $0.880^{* *}$ & $0.982^{* * *}$ \\
\hline & DMR & & & & & 1 & $0.947^{* * *}$ \\
\hline & SC & & & & & & 1 \\
\hline
\end{tabular}

Significant at $P \leq 0.05,0.01$, or 0.001 , respectively. 
weight) and main qualities (SG, DMR, and SC). And also, between these main qualities, high positive correlation was observed. That was, these results agreed with those obtained from upland by many workers (Kim, 1991; Lee, 2002; Majid et al., 2011). It was recognized that there was no difference in general tendencies of yield and qualities between paddy field cultivation and upland cultivation.

In conclusion, it was possible to produce potato before rice transplanting using drained paddy fields located in representative two locations of potato spring cropping. And the characteristics in growth and quality of potato grown at paddy field were similar to those generally well known in potato upland cultivation. Paddy field was thought to be more favorable than upland in terms of available soil moisture supply against spring drought. Further research, however, was needed to increase the soil temperature. Also, there was a large gap in marketable yield depending on difference in tuber enlargement according to locations and cultivars, and therefore preliminary review on proper cultivar according to location seemed to be needed for high yield.

\section{Literature Cited}

Brandt, F.I. 1979. Computer programming technique for selection of processing condition for optimum color development in potato chips. Diss. Int. B. 39:3219-3220. (Abstr.)

Brown, C.R. 2005. Antioxidants in potato. Amer. J. Potato Res. 82:163-172.

Burton, W.G. 1966. The Potato: A survey of its history and of the factors influencing its yield, nutritive value, quality and storage. H. Veenman and Sonen, N.V., Wageningen.

Burton, W.G. 1989. The potato. 3rd ed. Longman Scientific \& Technical Publisher, Essex, UK.

Cho, H.M., Y.E. Park, J.H. Cho, and S.Y. Kim. 2003. Historical review of land race potatoes in Korea. J. Kor. Soc. Hort. Sci. 44:838-845.

Clarkson, V.A. 1960. Effect of black polyethylene mulch on soil microclimate temperature and nitrate level. Agron. J. 52:307309.

Collins, W.B. 1976. Effects of mulches on emergence and yield of potatoes. Can. J. Plant Sci. 56:877-880.

Courter, H.J. 1964. Comparisons of paper and polyethylene mulching on yield of certain vegetable crops. Proc. Amer. Soc. Hort. Sci. 85:526-531.

Cui, R.X. 1999. Soil environment, growth and yield of potato as influenced by mulching materials in spring and fall season culture. PhD Diss., Seoul Natl. Univ., Seoul, Korea.

Cutter, E.G. 1992. Structure and development of the potato plant, p. 65-161. In: H. Paul (ed.). The potato crop: The scientific basis for improvement. Chapman \& Hall, London.

Ekern, P.C. 1967. Soil moisture and soil temperature changes with the use of black vapor-barrier mulch and their influence on pineapple. Soil Sci. Soc. Amer. Proc. 31:270-275.

Ekin, Z. 2011. Some analytical quality characteristics for evaluating the utilization and consumption of potato (Solanum tuberosum L.) tubers. African J. Biotech. 10:6001-6010.

Ezekiel, R., B. Singh, and J. Gopal. 2003. Relationship between under water weight and specific gravity, dry matter and starch content of potatoes grown in India. Potato J. 30:233-239.

Food and Agricultural Organization (FAO). 2008. International year of the potato 2008-The potato. FAO, Rome, Italy. http://www.potato2008.org/en/index.html.

Genung, W.G. 1970. Flooding experiments for control of wireworms attacking vegetable crops in the everglades. Florida Entomologist 53:55-63.

Hanneman, R.E. Jr. 1989. The potato germplasm resource. Amer. Potato J. 66:655-667.

Ifenkwe, O.P., E.J. Allen, and D.C.E. Wurr. 1974. Factors affecting the relationship between tuber size and dry matter content Amer. Potato J. 51:233-241.

Iritani, W.M. 1981. Growth and harvest stress and processing quality of potatoes. Amer. Potato J. 58:71-80.

Jang, Y.R., Y.H. Lim, and K. Kim. 2011. Effect of content of potato tuber component and potato variety on the bioethanol production. Korean J. Crop Sci. 56:273-278.

Jefferies, R.A. and D.K.L. Mackerron. 1987. Aspect of the physiological basis of cultivar differences in yield of potato under droughted and irrigated conditions. Potato Res. 30:201217.

Katan, J. 2000. Physical and cultural methods for the management of soil-borne pathogens. Crop Prot. 19:725-731.

Kawchuck, L.M., D.R. Lynch, J. Thomas, B. Penner, D. Sillito, and F. Kulcsar. 1996. Characterization of Solanum tuberosum simple sequence repeats and application to potato cultivar identification. Amer. Potato J. 73:325-335.

Kim, S.Y. 1991. Effect of nitrogen application, soil moisture and cultural practices in the growth, tuber yield and dry matter content of potatoes. PhD. Diss., Dankook Univ., Seoul, Korea.

Kleinkopf, G.E., D.T. Westermann, M.J. Wille, and G.D. Kleinshmidt. 1987. Specific gravity of russet burbank potatoes. Amer. Potato J. 64:579-587.

Kolasa, K.M. 1993. The potato and human nutrition. Amer. J. Potato Res. 70:375-384.

Kolbe, H. and S. Stefan-Beckmann. 1997. Development, growth and chemical composition of the potato crop (Solanum tuberosum L.). II. Tuber and whole plant. Potato Res. 40:135-153.

Korea Agricultural Trade Information (KATI). 2011. Export statistics. http://www.kati.net/homepage/atkati/tra_sta/tra_sta_domeSta _160.jsp?MENUCODE=125.

Lee, E.S. 2002. Studies on cropping system for quality improvement in potato (Solanum tuberosum L.) chip processing. $\mathrm{PhD}$. Diss, Dongguk Univ., Seoul, Korea.

Lisinska, G. and W. Leszczynski. 1989. Potato science and technology. Elsevier Applied Science, London, UK. p. 16-43, 166-233.

Love, S.L. and J.J. Pavek. 2008. Positioning the potato as a primary food source of vitamin C. Amer. J. Potato Res. 85:277-285.

MacKerron, D.K.L. and P.D. Waister. 1985. A simple model of potato growth and yield Part I. Model development and sensitivity analysis. Agri. and Forest Meteorology 34:241-252. 
MacKerron, D.K.L. and R.A. Jefferies. 1986. The influence of early soil moisture stress on tuber numbers in potato. Potato Res. 29:299-312.

Majid, K., S. Reza, G. Roza, J.S. Shahzad, and Z.M. Roghayyeh. 2011. Correlation and path analysis between yield and yield components in potato (Solanum tubersum L.). Middle-East J. Sci. Res. 7:17-21.

Miller, G.L. 1959. Use of dinitrosalicilic acid reagent for determination of reducing sugar. Analytical Chem. 31:426-428.

Ministry for Food, Agriculture, Forestry and Fisheries (MIFAFF). 2011. Food, Agriculture, Forestry and Fisheries statistical yearbook. MIFAFF, Gwacheon, Korea. http://ebook.mifaff.go.kr/ src/viewer/main.php?host $=$ main \&site $=20110919 \_200232 \&$ pagenum $=\&$ category $=\&$ page $=\&$ search $=\&$ mem .

Park, Y.E. 2003. Establishment of breeding system for processing potato through the analysis of variation patterns and selection efficiency in specific gravity and glucose contents. $\mathrm{PhD}$. Diss., Kangwon Natl. Univ., Chuncheon, Korea p. 79-86.

Pavlista, A.D. 1997. Potato types: Their characteristics and uses. Amer. Biol. Teacher 59:26-34.

Robins, J.S. and C.E. Domingo. 1956. Potato yield and tuber shape as affected by severe soil-moisture deficits and plant spacing. Agron. J. 48:488-492.

Rural Development Administration (RDA). 2003. Analysis standard of agricultural test and Research. RDA, Suwon, Korea.

Rural Development Administration (RDA). 2005. Potato series (revision). RDA, Suwon, Korea.

Schippers, P.A. 1976. The relationship between specific gravity and percentage dry matter in potato tubers. Amer. Potato J. 53:111-122.
Shimsi, D. and M. Susnoschi. 1985. Growth and yield studies of potato development in a semi arid region. 3. Effect of water stress and amounts of nitrogen top dressing on physiological indices and on tuber yield and quality of several cultivars. Potato Res. 28:177-191.

Smith, O. 1959. Progress in potato chip research. Production and Tech. Div. Mtg. Potato Chip Inst. Intern. p. 3-6.

Stakman, W.P. 1974. Measuring soil moisture, p. 221-251. In: J. Kessler, T. Beekman, M.G. Bos, R.H. Messemacckers van de Graff, and N.A. de Ridder. Drainage principles and applications. Vol III. Surveys and investigations. ILRI, Wageningen, The Netherland.

Stover, R.H. 1979. Flooding of soil for disease control, p. 19-28. In: D. Mulder (ed.). Soil disinfestation. Elsevier, Amsterdam.

Swiezynski, K.M., Sykala, A., and J.K. Wroblewska. 1978. Differences in early growth of shoots and roots in potato clones. Potato Res. 21:241-248.

Vakis, N.J. 1978. Specific gravity, dry matter content and starch content of 50 potato cultivars grown under cyprus conditions. Potato Res. 21:171-181.

van Es, A. and K.J. Hartmans. 1987. Structure and chemical composition of the potato, p. 15-78. In: A. Rastovski and A. van Es (eds.). Storage of potatoes: Post-harvest behaviour, store design, storage practice, handling. Pudoc, Wageningen.

van Loon, C.D. 1981. The effect of water stress on potato growth, development, and yield. Amer. Potato J. 58:51-69.

Verma, S.C., V.P. Malhotra, K.C. Joshi, and T.R. Sharma. 1971. Specific gravity and dry matter content of potato. Potato Res. 14:94-95. 